\title{
Biocatalyst: Cellulase Production in Solid State Fermentation (SSF) Using Rice Bran as Substrate
}

\author{
Uthralakshmi Navaneethapandian ${ }^{1}$ (D), A. Ganesh Kumar ${ }^{2}$, K. Liduja ${ }^{1}$, R. Jayachithra, Narendrakumar \\ Gopakumaran ${ }^{*}$ (iD
}

1 Department of Biotechnology, School of Bio and Chemical Engineering, Sathyabama Institute of Science and Technology, Chennai - 600119, Tamil Nadu, India

2 Marine Biotechnology, National Institute of Ocean Technology, Chennai - 600 100, Tamil Nadu, India

* Correspondence: gnaren22@gmail.com;

Received: 10.06.2020; Revised: 30.06.2020; Accepted: 1.07.2020; Published: 3.07.2020

\begin{abstract}
The study was aimed to analyze the biological transformation of cellulose in rice bran by Aspergillus flavus SB04 in SSF for 28 days. The culture conditions such as pH, temperature, moisture content were optimized for the effective production of the enzyme in SSF. Effect of carbon and nitrogen sources on cellulase production was further estimated in SMF and were quantified for $24 \mathrm{hrs}$ intervals for 7 days Maximum cellulase production for rice bran was observed to be high in glucose (carbon source) and yeast extract (nitrogen source) at initial moisture $75 \mathrm{ml}, \mathrm{pH} 6$, temperature $33^{\circ} \mathrm{C}$ and fermentation period was 14th day that was optimized using response surface methodology. The enzyme production was analyzed individually by dinitrosalicylic acid (DNS) method, Lowry protein estimation, and filter paper assay. The lignocellulosic degradation was observed and confirmed by FTIR and SEM. The degradation of cellulose periodically increases after 7 days, which influences the yield of cellulase enzyme.
\end{abstract}

Keywords: Cellulase; JMP10; RSM; SEM; FTIR.

(C) 2020 by the authors. This article is an open-access article distributed under the terms and conditions of the Creative Commons Attribution (CC BY) license (https://creativecommons.org/licenses/by/4.0/).

\section{Introduction}

Cellulose is a polymer of glucose units connected by $\beta-1,4$ bonds [1-3]. It is the most profused organic material and a major mechanical support constituent of flora and a renewable resource of energy in the earth. Cellulose comprising agrowastes serves as an inexpensive carbon source and other bioactive compounds. So, agrowaste can be effectively used as an alternative energy source to produce different products [4-6]. Cellulose is chiefly reduced by cellulase that is generally produced by microorganisms. Cellulases can efficiently breakdown cellulose into glucose units via the synergistic actions of the enzymes, known as an endo- $\beta-1,4$ glucanase, cellobiohydrolase, and $\beta$-d-glucosidase [7].

Isolation and screening of highly cellulolytic filamentous fungi were isolated from different sources such as soil, industrial effluent, seeds fruit, vegetable, bread, and wood. Although a large number of microorganisms were identified as the potential decomposers of cellulose, the research studies revealed that Trichoderma viridae, Aspergillus niger, and Aspergillus flavus are found to be relatively high in occurrence [8]. Fungi isolates are reported to be potential cellulase secretors than bacteria because of their accumulated mycelium that reduces the separation cost [9]. Due to the increase in demand for more thermostable, highly active, and specific cellulose, this study was designed to screening the native fungi isolate as 
hyper-producers of cellulases by investigating the cellulose system of local fungi keeping in view the importance and application of the cellulases [10]. Hence the commercial demand in the near future of cellulase in industries has become an attentive study.

\section{Materials and Methods}

\subsection{Microorganism.}

A pure culture of A. flavus was isolated from soil and preserved in the Department of Biotechnology, Sathyabama Institute of Science and Technology. The fungus was maintained as direct stock culture from which inoculums were prepared. It was grown on PDA slants at $28^{\circ} \mathrm{C}$ for 5 days and stored at $4^{\circ} \mathrm{C}$ with regular sub-culturing [11].

\subsection{Preparation of substrates.}

Rice bran (RB) is one of the most popular agro-industrial waste residues preferred by many researchers to produce value-added metabolites by SSF from various microorganisms [4]. The SSF substrates RB is obtained from the local market, Chennai. The RB substrates were cleaned, sun-dried, and ground to a fine powder. Rice by-products are used to generate cellulase under SSF and have many operational benefits, including low cost, product stability, require low space, etc. [12].

\subsection{Pre-treatment of substrates.}

Powdered RB substrates were pre-treated by soaking in $1 \% \mathrm{NaOH}$ solution in the ratio of 1:10 (substrate: $\mathrm{NaOH}$ solution) overnight at room temperature. The treated substrates were filtered and washed with distilled water until the $\mathrm{pH}$ reaches 7.0 in the substrate. Finally, the pre-treated substrates were autoclaved at $121^{\circ} \mathrm{C}$ for 15 minutes [13].

\subsection{Response surface methodology (RSM).}

The parameters $\mathrm{pH}$, temperature, moisture content, and incubation time were optimized further by response surface methodology - central composite design [14]. The software used for the Design of Experiment (DOE) was JMP 10.

\subsection{Optimization of cellulase production in SSF.}

The influence of temperature $\left(35\right.$ to $55^{\circ} \mathrm{C}$ ), $\mathrm{pH}$ (4 to 8 ), the incubation period (24 to $168 \mathrm{~h}$ ), particle size, inoculum size, moisture content, carbon (CMC, glucose, sucrose, and maltose) and nitrogen sources (yeast extract, ammonium nitrate, peptone, and sodium nitrate) was tested for 28 days at $28-30^{\circ} \mathrm{C}$ to optimize the production of cellulase by fungal isolate grown in RB. The cellulase activity is measured using reducing sugar and protein estimation method [15-18].

\subsection{Inoculum preparation.}

To the fungal slants, $5 \mathrm{~mL}$ of sterile distilled water was dispensed, and the spores were dislodged using an inoculation loop. The prepared spore suspensions were transferred to the conical flask under aseptic conditions [19]. 


\subsection{Enzyme production.}

The culture was grown in a $150 \mathrm{~mL}$ Erlenmeyer flask, which contains $30 \mathrm{~g}$ of RB substrate mixed with sterile minimal salt medium (MSM). The MSM of composition given below was used in SSF experiments. The MSM composition includes (g/L): Ammonium sulphate-10g; Potassium phosphate-3g; Magnesium sulphate- $0.5 \mathrm{~g}$; Calcium chloride $-0.5 \mathrm{~g}$, Yeast extract-7gm and Dextrose-15g. The initial moisture content of the RB mixed with MSM was determined before the onset of the experiment [20].

\subsection{Scanning electron microscopy.}

The RB from SSF of 0th and 28th day as well as untreated RBs (control) were initially dried in a hot air oven at $60^{\circ} \mathrm{C}$ for $8 \mathrm{~h}$, and the samples were selected using a light microscope. The selected samples were coated with the gold ions, and the coated stubs were placed in FESEM module, and samples were analyzed at different magnifications.

\subsection{Fourier transform infrared spectroscopy (FTIR).}

The dried RB samples obtained at different time intervals were mixed with $\mathrm{KBr}$ of spectroscopic grade $1 \mathrm{MPa}$. The spectra were then subjected to baseline correction, and the bands were studied in Perkin Elmer infrared spectrophotometer to quantify the changes in the chemical structure of the lignocellulose matrix [21, 22].

\subsection{FPase assay for cellulases.}

To test cellulase activity, $1 \mathrm{~mL}$ buffer was added with a $0.5 \mathrm{~mL}$ enzyme. At least two dilutions must be made of each enzyme sample investigated. One dilution should release slightly less than $2 \mathrm{mg}$ of glucose in the reaction conditions. Whatman filter $(50 \mathrm{~mm})$ paper strip was inserted into the test tube and incubated at $50^{\circ} \mathrm{C}$ for $1 \mathrm{~h}$. The mixture was boiled for $20 \mathrm{~min}$, followed by an additional $20 \mathrm{~mL}$ water, and the mixture was filtered with a glass filter paper. The filtrate was measured against reference at $540 \mathrm{~nm}$. A linear glucose standard was constructed using the absolute amounts of glucose $(0.5 \mathrm{ml} / \mathrm{mg})$ plotted against $540 \mathrm{~nm}$. Using this standard, the absorbance values of the sample tubes (after subtraction of enzyme blank) were converted into glucose units [23-25].

\section{Results and Discussion}

\subsection{Optimization in SSF.}

\subsubsection{Effect of incubation period on enzyme production.}

The incubation period is directly related to the production of enzymes and other metabolic activity up to a certain extent. The incubation period to achieve peak cellulase activity by the isolate Aspergillus flavus was at 3rd day, which is suitable for the commercial point of view [13]. Sirohi et al. [26] reported that the precise condition of SSF influences greater production of value-added products than the submerged fermentation.

\subsubsection{Effect of $\mathrm{pH}$ on enzyme production.}

Cellulase yield by Aspergillus flavus appears to depend on $\mathrm{pH}$ value. It was then observed to decrease with more increase in $\mathrm{pH}$, indicating that there was a reduction in the 
cellulase activity. All three methods of enzyme estimation: DNS, Lowry's et al., and Filter Paper Assay were showed to be high at $\mathrm{pH}$ 6. The significant saccharification is influenced by the optimal temperature and the substrate concentration along with $\mathrm{pH}$ [27].

\subsubsection{Effect of moisture content on enzyme activity.}

Ricebran was used in solid-state fermentation for the production of cellulase. In this study, we investigated a moisture range for rice bran $(75 \mathrm{ml})$ was used in order to accelerate the growth of Aspergillus species to generate cellulase production. The biomass coverage and spore formation on the substrate surface was positively associated with the increase in moisture content, indicating that the higher the moisture, the higher growth rates were within the moisture range.

\subsection{RSM.}

Like the design of the experiment, the estimation of cellulase activity was performed, and the results were tabulated, and maximum productivity was identified.

The data were subjected to analysis of variance, and the contour plot was generated by using JMP 10.0.0. The regression analysis showed that $93 \%$, and the best fit of the model was also justified.[28]. Figure 1 showing the interaction between the actual and predicted values. Figure 2 shows the prediction profile of various parameters. Table 2 shows the parameter estimates and gives a t-test for the hypothesis that it equals zero. Table 3 shows scaled estimates (Nominal factors expanded to all levels). Figure 3 shows the Bivariate fit of enzyme activity by $\mathrm{pH}$, Temperature, Moisture content, Incubation time, which is a continuous relationship study between the variables in a specific time frame. The values were shown in a scatterplot. The $\mathrm{R}^{2}$ value was considered to be significant. In the summary of the fittable (Table 1), the regression analysis values show a somewhat similar relationship between $\mathrm{R}^{2}$ and Adjusted $\mathrm{R}^{2}$ values. The experimental values and the predicted results were significantly correlated with the obtained $R^{2}$ value (0.93), and also the $R^{2}$-adj was close to the value of $R^{2}$. Based on the results, the yield of the enzyme on the various condition can be predicted [27]. RSM study has reported that it could assist in attaining the maximum enzyme production with the evaluated different parameters on tea residue for the mixed strains (B. subtilis, A. niger, S. cerevisiae) on SSF [(29]. Figure 4. Influence of variable represented in contour plot for Biomass production: a) $\mathrm{pH}$ vs. Temperature b) Incubation time vs. Temperature c) Incubation time vs. $\mathrm{pH}$.

\subsection{Response Enzyme activity.}

Actual by Predicted Plot

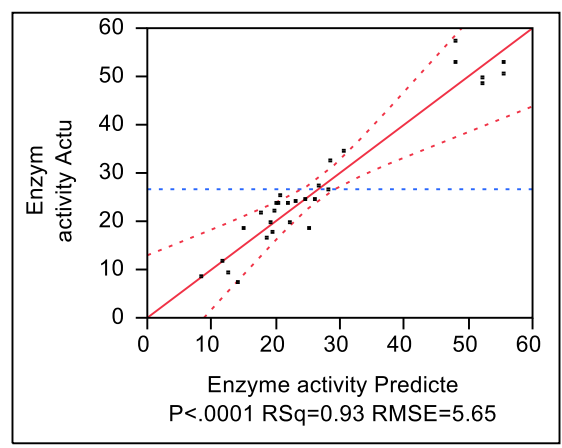

Figure 1. Least squares fit graph for actual and predicted. 
Table 1. Summary of Fit.

\begin{tabular}{l|l}
$\mathrm{R}^{2}$ & 0.931089 \\
\hline $\mathrm{R}^{2} \mathrm{Adj}$ & 0.846275 \\
\hline Root Mean Square Error & 5.656044 \\
\hline Mean of Response & 26.63067 \\
\hline Observations (or Sum Wgts) & 30
\end{tabular}

Table 2. Parameter Estimates.

\begin{tabular}{l|l|l|l|l} 
Term & Estimate & Std Error & t Ratio & Prob $|\mathbf{t}|$ \\
\hline Intercept & 51.878333 & 2.30907 & 22.47 & $<.0001^{*}$ \\
\hline $\mathrm{pH}(4,8)$ & 0.26875 & 1.154535 & 0.23 & 0.8196 \\
\hline Temperature $(25,45)$ & -1.020417 & 1.154535 & -0.88 & 0.3928 \\
\hline Moisture content (30,70) & -0.197083 & 1.154535 & -0.17 & 0.8671 \\
\hline Incubation time (3,5) & -1.337917 & 1.154535 & -1.16 & 0.2674 \\
\hline $\mathrm{pH}$ Temperature & -1.055625 & 1.414011 & -0.75 & 0.4686 \\
\hline pH*Moisture content & -1.235625 & 1.414011 & -0.87 & 0.3981 \\
\hline Temperature*Moisture content & 1.185625 & 1.414011 & 0.84 & 0.4169 \\
\hline $\mathrm{pH}$ Incubation time & 1.083125 & 1.414011 & 0.77 & 0.4574 \\
\hline Temperature*Incubation time & 0.369375 & 1.414011 & 0.26 & 0.7980 \\
\hline Moisture content*Incubation time & -0.133125 & 1.414011 & -0.09 & 0.9264 \\
\hline $\mathrm{pH}$ pH & -8.322396 & 1.079969 & -7.71 & $<.0001^{*}$ \\
\hline Temperature*Temperature & -9.349896 & 1.079969 & -8.66 & $<.0001^{*}$ \\
\hline Moisture content*Moisture content & -8.922396 & 1.079969 & -8.26 & $<.0001^{*}$ \\
\hline Incubation time*Incubation time & -4.964896 & 1.079969 & -4.60 & $0.0005^{*}$ \\
\hline Block [1] & 0.2593333 & 1.460384 & 0.18 & 0.8618 \\
\hline Block [2] & 3.7343333 & 1.460384 & 2.56 & $0.0239^{*}$
\end{tabular}

Table3. Scaled Estimates (Nominal factors expanded to all levels).

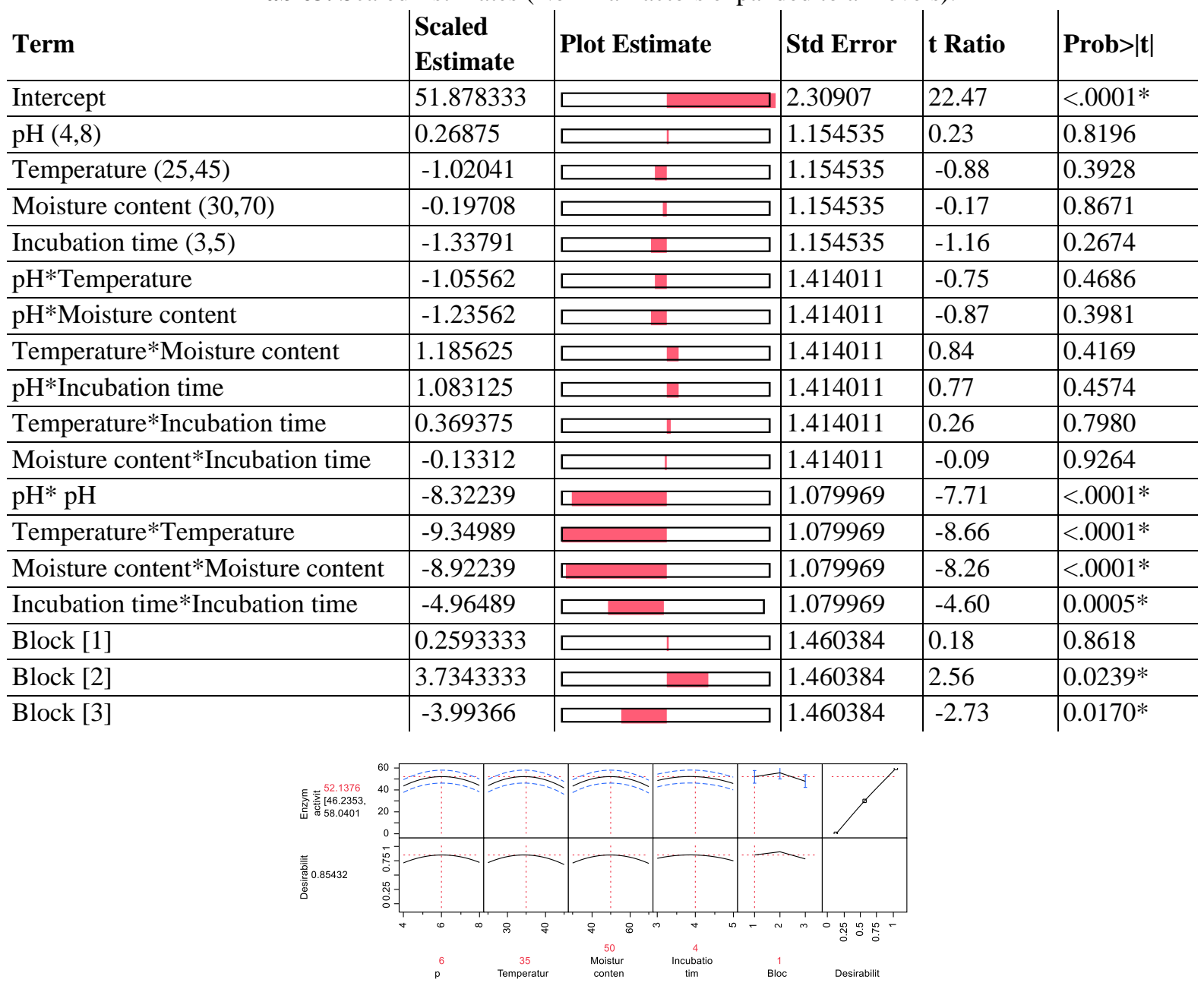

Figure 2. Prediction Profiler. 
Fit Y by X Group
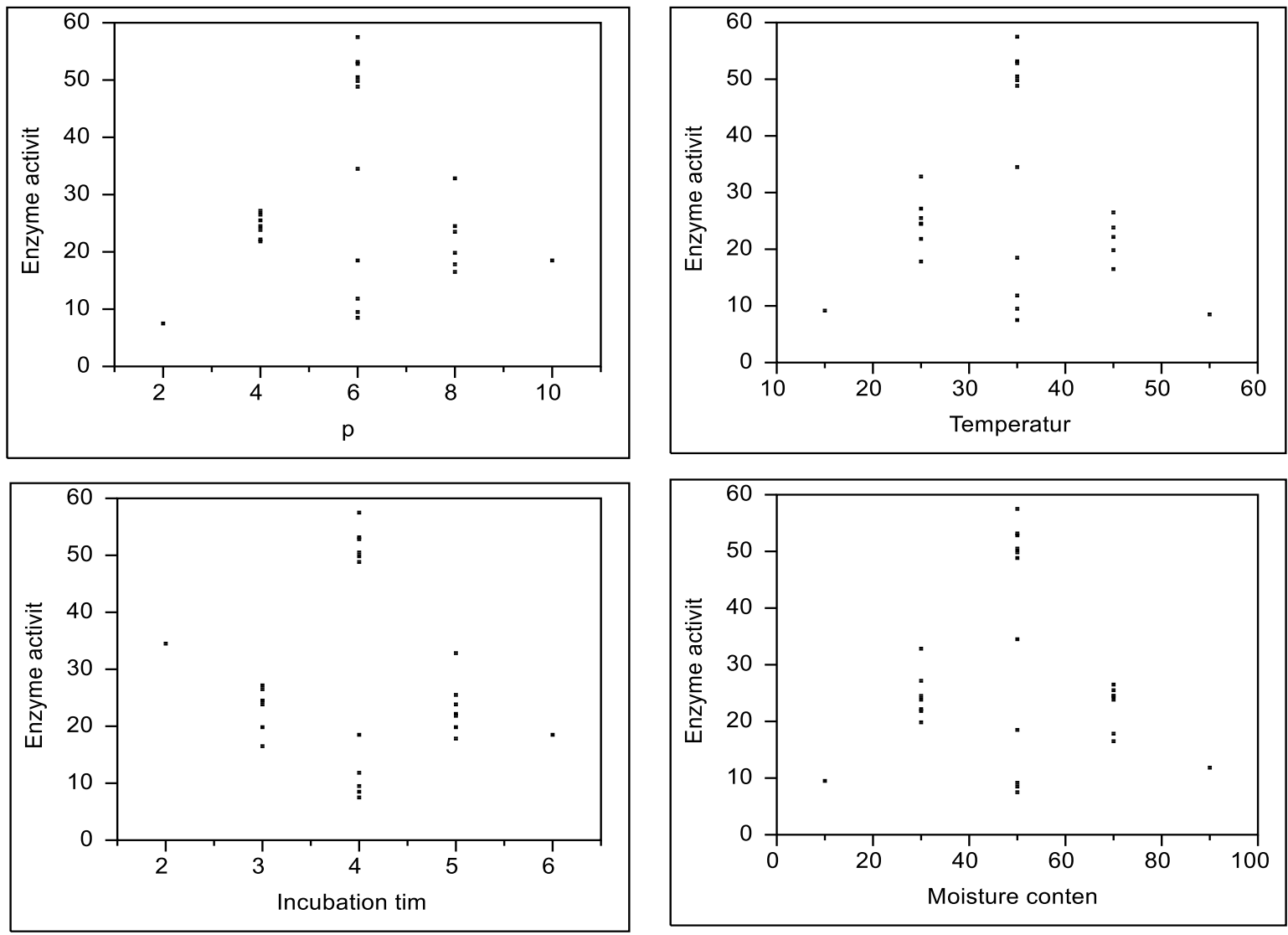

Figure 3. Bivariate fit of enzyme activity by $\mathrm{pH}$, Temperature, Moisture content, Incubation time.
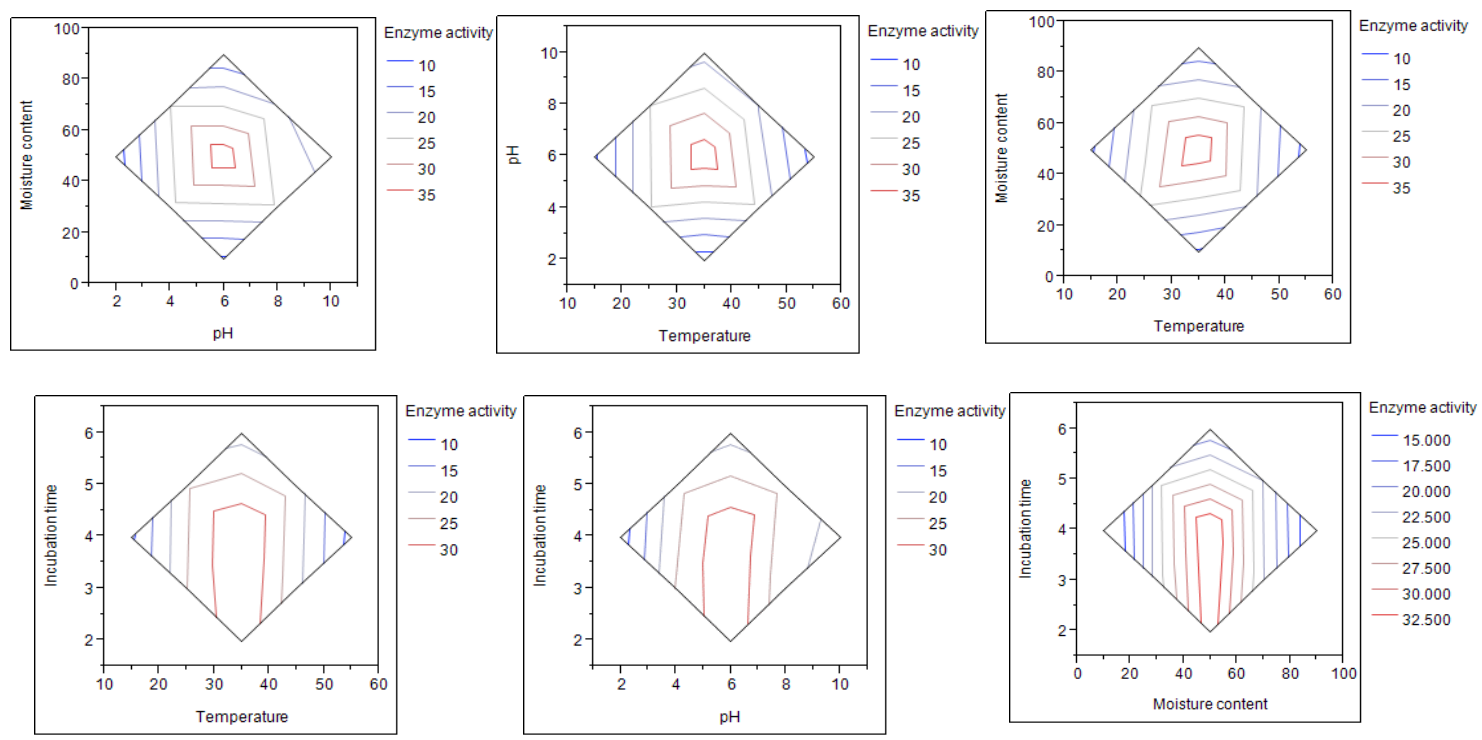

Figure 4. Influence of variable represented in contour plot for Biomass production: a) pH vs. Temperature b) Incubation time vs. Temperature c) Incubation time vs. $\mathrm{pH}$.

\subsection{Effect of carbon source.}

Cellulase production by Aspergillus flavus was significantly influenced by the type of carbon source in MSM. Among the carbon source used, glucose influenced cellulase production (Table 4). Glucose was the most effective as a sole carbon source for cellulase production in both SSF [30-32]. Carbon sources (methylcellulose, hydroxyethylcellulose, 
glucose) acts as an effective inducer for the secretion of cellulase in many fungal organisms [33]. A report revealed that the olive pomace also renders as a good carbon source for the production of cellulase in both liquid and solid-state fermentation [34].

Table 4. Results for carbon source estimation in SMF.

\begin{tabular}{l|l|l|l|l|l} 
Content & $\mathbf{1}^{\text {st }} \mathbf{d a y}(\mathbf{m g} / \mathbf{m l})$ & $\mathbf{2}^{\text {nd }} \mathbf{d a y}(\mathbf{m g} / \mathbf{m l})$ & $\mathbf{3}^{\text {rd }} \mathbf{d a y}(\mathbf{m g} / \mathbf{m l})$ & $\mathbf{4}^{\text {th }} \mathbf{d a y}(\mathbf{m g} / \mathbf{m l})$ & $\mathbf{5}^{\text {th }} \mathbf{d a y}(\mathbf{m g} / \mathbf{m l})$ \\
\hline CMC & $19.1 \pm 0.2$ & $21.2 \pm 0.5$ & $22.2 \pm 0.4$ & $19.2 \pm 0.2$ & $16.2 \pm 0.9$ \\
\hline Sucrose & $21.2 \pm 0.3$ & $19.2 \pm 0.1$ & $18.2 \pm 0.8$ & $11.2 \pm 0.1$ & $31.2 \pm 0.2$ \\
\hline Glucose & $18.2 \pm 0.4$ & $21.2 \pm 0.6$ & $38.2 \pm 0.1$ & $40.2 \pm 0.4$ & $45.2 \pm 0.4$
\end{tabular}

\subsection{Effect of nitrogen source.}

Cellulase production by Aspergillus flavus was significantly influenced by the type of nitrogen source in MSM (Figure 5) (Table 5). Yeast was the most effective as a sole nitrogen source for cellulase production in SSF. The optimal conditions of carbon and nitrogen sources with other physical parameters highly influenced the production of multienzyme in A.clavatus and P.citrinum [35].

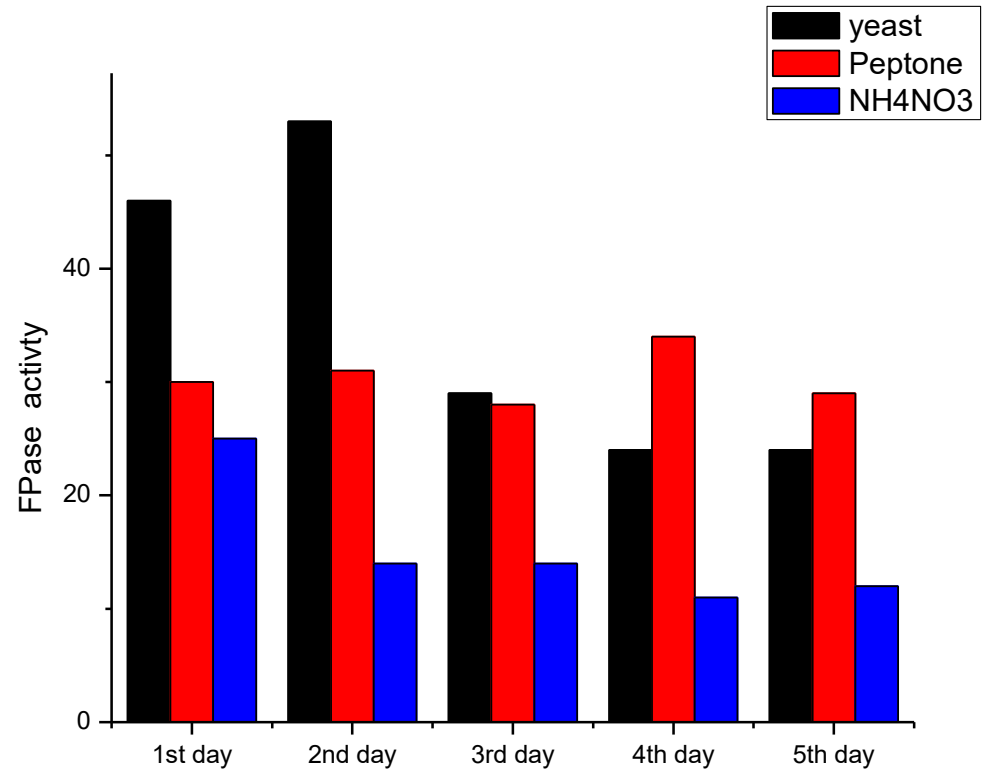

Figure 5. Effect of nitrogen source on FPase.

Table 5. Effect of various nitrogen source on FPase.

\begin{tabular}{l|l|l|l|l|l} 
Content 2\% & $\mathbf{1}^{\text {st }}$ day $(\mathbf{m g} / \mathbf{m l})$ & $\mathbf{2}^{\text {nd }} \mathbf{d a y}(\mathbf{m g} / \mathbf{m l})$ & $\mathbf{3}^{\text {rd }} \mathbf{d a y}(\mathbf{m g} / \mathbf{m l})$ & $\mathbf{4}^{\text {th }} \mathbf{d a y}(\mathbf{m g} / \mathbf{m l})$ & $\mathbf{5}^{\text {th }} \mathbf{d a y}(\mathbf{m g} / \mathbf{m l})$ \\
\hline Yeast & $46.2 \pm 0.5$ & $53.2 \pm 0.9$ & $29.4 \pm 0.4$ & $24.2 \pm 0.1$ & $24.4 \pm 0.2$ \\
\hline Peptone & $30.1 \pm 0.5$ & $31.3 \pm 0.5$ & $28.5 \pm 0.6$ & $34.9 \pm 0.2$ & $29.2 \pm 0.6$ \\
\hline $\mathrm{NH}_{4}\left(\mathrm{NO}_{3}\right)_{2}$ & $25.4 \pm 0.9$ & $14.1 \pm 0.1$ & $14.9 \pm 0.1$ & $11.7 \pm 0.7$ & $12.6 \pm 0.1$
\end{tabular}

3.6. Scanning electron microscope (SEM).

The SEM was used to study the morphological changes of cellulosic degradation by Aspergillus flavus. The longer incubation period of 28 days was required for the breakdown of cellular fibers(Fig 6). The enzyme degradation was observed on $0^{\text {th }}$ day and $28^{\text {th }}$ day. The cellulose reacted with the enzymes secreted by the organism and resulted in the changes in surface morphology, indicating the enzyme degradation. The substrate surface was degraded on $28^{\text {th }}$ day compared to $0^{\text {th }}$ day (Figure 6). 


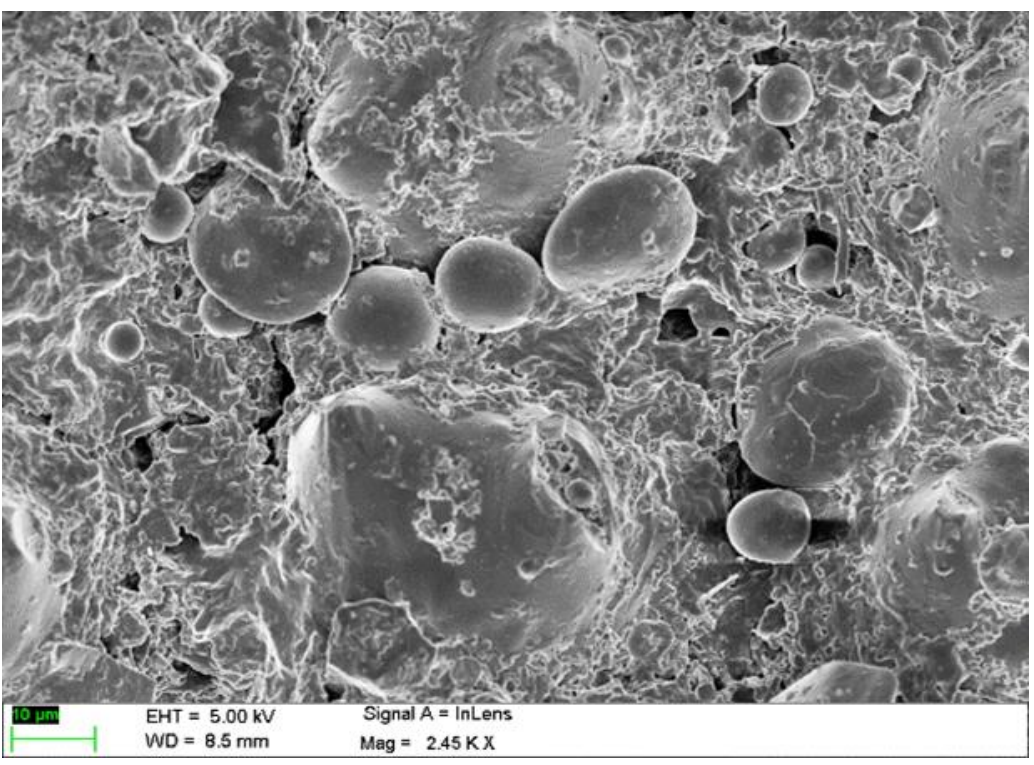

Figure 6. SEM.

\subsection{Fourier transform infrared spectroscopy (FTIR).}

The FTIR spectra for fungal treated samples and the compounds present on different days are the compounds observed on $0^{\text {th }}$ day in rice bran [36-38] (Figure 7).

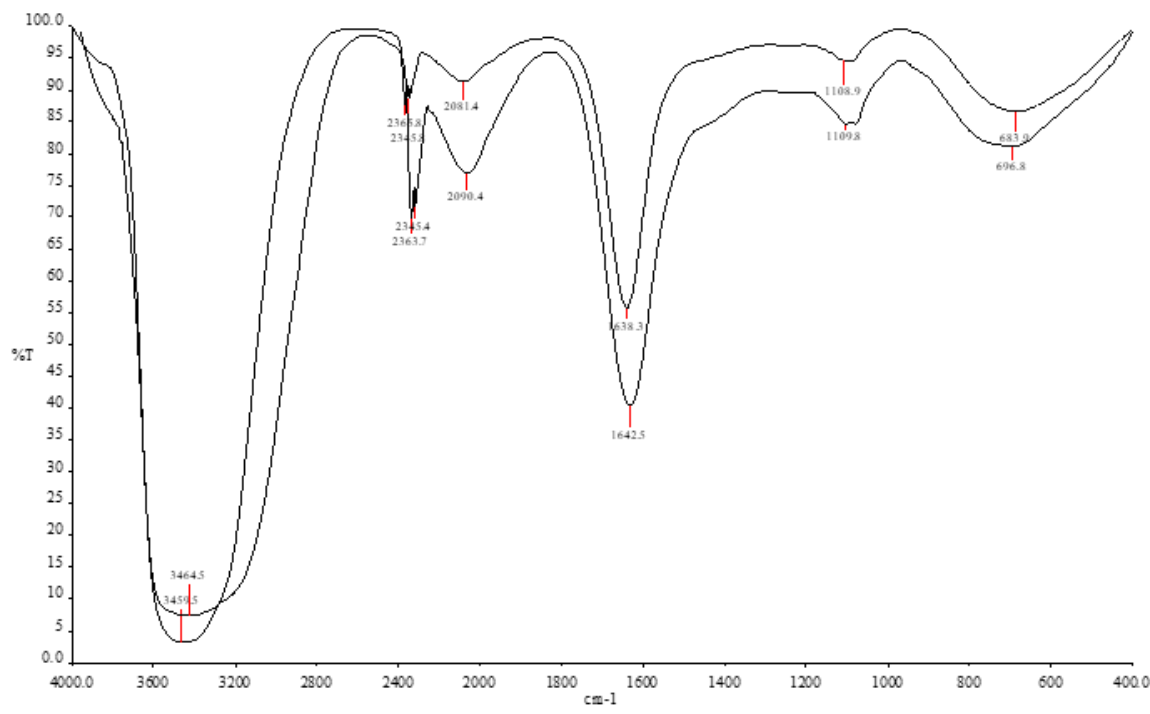

Figure 7. FTIR results.

Strong hydrogen-bonded $(\mathrm{O}-\mathrm{H})$ stretching absorption is seen at $3901 \mathrm{~cm}-1$ and $(\mathrm{C}-\mathrm{H})$ stretch at $2928 \mathrm{~cm}-1$. In addition, well defined peaks were shown at $1640 \mathrm{~cm}^{-1}, 1261 \mathrm{~cm}^{-1}$, $1121 \mathrm{~cm}^{-1}, 899 \mathrm{~cm}^{-1}, 619 \mathrm{~cm}^{-1}$ and $592 \mathrm{~cm}^{-1}$.

The compounds observed on $7^{\text {th }}$ day in rice bran (Fig 7) $3459.5 \mathrm{~cm}^{-1}$ indicate $\mathrm{O}-\mathrm{H}$ group (alcohol), $2081.4 \mathrm{~cm}^{-1}$ indicates $-\mathrm{C} \equiv \mathrm{C}$ - represent alkynes. $1638.3 \mathrm{~cm}^{-1}$ indicates $\mathrm{C}=\mathrm{C}$ that represents alkene, aromatic ring. $1108.9 \mathrm{~cm}^{-1}$ indicate $\mathrm{C}-\mathrm{O}$ that represent secondary alcohols, $683 \mathrm{~cm}^{-1}$ indicate $\mathrm{C}-\mathrm{Br}$ that represent alkyl halides. The FT-IR spectra of rice straw reports showed similar peaks around $3300 \mathrm{~cm}-1$ and 1640-1 with the hydroxyl bond $(\mathrm{O}-\mathrm{H})$ stretching and bend of free cellulase[39]

The compounds observed on $14^{\text {th }}$ day in rice bran $3821.7 \mathrm{~cm}^{-1}$ indicate $\mathrm{O}-\mathrm{H}$ group (alcohol), $3802 \mathrm{~cm}^{-1}$ indicates $\mathrm{O}-\mathrm{H}$ represent alcohol group. $3462.8 \mathrm{~cm}^{-1}$ indicate $\mathrm{N}-\mathrm{H}$ that 
represents primary amine or amide. $1636 \mathrm{~cm}^{-1}$ indicate $\mathrm{C}=\mathrm{C}$ that represents alkene, aromatic ring, $1083.8 \mathrm{~cm}^{-1}$ indicate $\mathrm{C}-\mathrm{O}$ that represent secondary alcohol, $702 \mathrm{~cm}^{-1}$ represent phenyl group.

The compounds observed on $21^{\text {st }}$ day in rice bran $3464.5 \mathrm{~cm}^{-1}$ indicate $\mathrm{O}-\mathrm{H}$ group (alcohol), $2090 \mathrm{~cm}^{-1}$ indicates $-\mathrm{C}$-represent alkyne. $1648.5 \mathrm{~cm}^{-1}$ indicate $\mathrm{C}=\mathrm{C}$ that represents alkene, aromatic ring. $1109.8 \mathrm{~cm}^{-1}$ indicate $\mathrm{C}-\mathrm{O}$ that represent secondary alcohol,696 $\mathrm{cm}^{-1}$ represent phenyl group The compounds observed on $28^{\text {th }}$ day in rice bran. The peaks were observed to be $3421 \mathrm{~cm}^{-1}, 2923 \mathrm{~cm}^{-1}, 1734 \mathrm{~cm}^{-1}, 1642 \mathrm{~cm}^{-1}, 1501 \mathrm{~cm}^{-1}, 1259 \mathrm{~cm}^{-1}, 1055 \mathrm{~cm}^{-1}$ and $618 \mathrm{~cm}^{-1}$ showing all the stretches of $\mathrm{O}-\mathrm{H}$ bond, aromatics, $-\mathrm{C}=\mathrm{C}$ bond, $-\mathrm{C}-\mathrm{N}$ bond and $\mathrm{C}-\mathrm{Cl}$ bond.

The immobilization of the enzyme helps in the reuse and storage of enzymes [40].

\section{Conclusions}

This study could establish that rice bran, which is usually disposed of could serve as ideal substrates for the production of cellulases. Hence, the technology using these cheap and readily available substrates for the production of cellulases in optimum quantities holds promise for the future. The results are significant for the study on cellulase production and provide a potential approach for the industries. The culture conditions were optimized for the higher yield of the cellulase enzyme. Rice bran was selected as the best substrate for cellulase production using Aspergillus flavus. Cellulase production with Aspergillus was highest at temperature $30^{\circ} \mathrm{C}, \mathrm{pH}-6.0$, and incubation time-14th day. The best carbon source and nitrogen source for the growth of Aspergillus flavus is glucose and yeast extract. The morphological changes wereobserved by SEM and FTIR analysis. The high activity of cellulase enzymes will be of use in various industrial and biotechnological applications.

\section{Funding}

This research received no external funding.

\section{Acknowledgments}

We would like to thank the management of Sathyabama Institute of Science and Technology for providing the laboratory facilities for this work.

\section{Conflicts of Interest}

The authors declare no conflict of interest.

\section{References}

1. Alvira, P.; Tomás-Pejó, E.; Ballesteros, M.; Negro, M.J. Pretreatment technologies for an efficient bioethanol production process based on enzymatic hydrolysis: A review. Bioresource Technology 2010, 101, 4851-4861, http://dx.doi.org/10.1016/j.biortech.2009.11.093.

2. Bayer, E.A.; Chanzy, H.; Lamed, R.; Shoham, Y. Cellulose, cellulases and cellulosomes. Current Opinion in Structural Biology 1998, 8, 548-557,http://dx.doi.org/10.1016/s0959-440x(98)80143-7.

3. Bellon-Maurel, V.; Orliac, O.; Christen, P. Sensors and measurements in solid state fermentation: a review. Process Biochemistry 2003, 38, 881-896, http://dx.doi.org/10.1016/s0032-9592(02)00093-6.

4. Bhargav, S.; Panda, B.P.; Ali, M.; Javed, S. ChemInform Abstract: Solid-State Fermentation. ChemInform 2008, 39,http://dx.doi.org/10.1002/chin.200830268.

5. Bhat, M.K. Cellulases and related enzymes in biotechnology. Biotechnology Advances 2000, 18, 355-383, http://dx.doi.org/10.1016/s0734-9750(00)00041-0. 
6. Utharalakshmi N, Kumar AG, Narendrakumar G. Optimization of cellulase producing Aspergillus flavus SB4 by solid state fermentation using response surface methodology (RSM)-CCD. Research Journal of Pharmacy and Technology2015, 8, 349,http://dx.doi.org/10.5958/0974-360x.2015.00058.x.

7. Caramihai, M.D.; Jecu, L. Modeling of Inhibitory Effect of Lignin Derivatives on the Cellulase Biosynthesis in Aspergillus niger Cultures. IFAC Proceedings Volumes 1997, 30, 209213,http://dx.doi.org/10.1016/s1474-6670(17)44434-x.

8. Sarsaiya, S.; Awasthi, S.K.; Awasthi, M.K.; Awasthi, A.K.; Mishra, S.; Chen, J. The dynamic of cellulase activity of fungi inhabiting organic municipal solid waste. Bioresource Technology 2018, 251, 411-415, https://doi.org/10.1016/j.biortech.2017.12.011.

9. Srivastava, N.; Srivastava, M.; Mishra, P.K.; Gupta, V.K.; Molina, G.; Rodriguez-Couto, S.; Manikanta, A.; Ramteke, P.W. Applications of fungal cellulases in biofuel production: Advances and limitations. Renewable and Sustainable Energy Reviews 2018, 82, 2379-2386, https://doi.org/10.1016/j.rser.2017.08.074.

10. Achar, S.; Cv, B.; Gudigar, S.; S.V, R. Bioprocessing of Areca husk in solid state fermentation for cellulase production using Trichoderma viride. Indian Journal of Applied Research 2011, 1, 15-7.

11. Loewenberg, J.R. Cyanide and the determination of protein with the folin phenol reagent. Analytical Biochemistry 1967, 19, 95-97,http://dx.doi.org/10.1016/0003-2697(67)90138-8.

12. Darabzadeh, N.; Hamidi-Esfahani, Z.; Hejazi, P. Optimization of cellulase production under solid-state fermentation by a new mutant strain of Trichoderma reesei. Food Science \& Nutrition 2019, 7, 572-578, https://dx.doi.org/10.1002/fsn3.852.

13. Narendrakumar, G.; Saikrishna, N.; Prakash, P.; Preethi, T. Analysis of gut flora from damp wood termites (trinervitermes spp.) and extraction, characterization of cellulase from the isolate. Asian Journal of Pharmaceutical and Clinical Research 2017, 10, 233,http://dx.doi.org/10.22159/ajpcr.2017.v10i6.17565.

14. Ganesh Kumar, A.; Sekaran, G.; Krishnamoorthy, S. Solid state fermentation of Achras zapota lignocellulose by Phanerochaete chrysosporium. Bioresource Technology 2006, 97, 1521-1528, http://dx.doi.org/10.1016/j.biortech.2005.06.015.

15. Ghose, T.K. Measurement of cellulase activities. Pure and Applied Chemistry 1987, 59, 257-268, http://dx.doi.org/10.1351/pac198759020257.

16. Kang, S.W.; Park, Y.S.; Lee, J.S.; Hong, S.I.; Kim, S.W. Production of cellulases and hemicellulases by Aspergillus niger KK2 from lignocellulosic biomass. Bioresource Technology 2004, 91, 153-156, http://dx.doi.org/10.1016/s0960-8524(03)00172-x.

17. Sundararaman, S.; Narendrakumar, G.; Sundari, N.; Amarnath, M.; Thayyil, P.J. Extraction of pectin from used citrus limon and optimization of process parameters using response surface methodology. Research Journal of Pharmacy and Technology2016, 9, 2246-2251,http://dx.doi.org/10.5958/0974360x.2016.00453.4.

18. Khokhar, I.; Mukhtar, I.; Mushtaq, S. Isolation and screening of amylolytic filamentous fungi. Journal of Applied Sciences and Environmental Management2011, 15,http://dx.doi.org/10.4314/jasem.v15i1.68442.

19. Klemm, D.; Heublein, B.; Fink, H.-P.; Bohn, A. Cellulose: Fascinating Biopolymer and Sustainable Raw Material. Angewandte Chemie International Edition 2005, 44, 33583393,http://dx.doi.org/10.1002/anie.200460587.

20. Malherbe, S.; Cloete, T.E. Lignocellulose biodegradation: Fundamentals and applications. Reviews in Environmental Science and Biotechnology 2002, 1, 105-114,http://dx.doi.org/10.1023/a:1020858910646.

21. Mandels, M.; Weber, J. The Production of Cellulases. Cellulases and Their Applications. American Chemical Society1969, 391-414,http://dx.doi.org/10.1021/ba-1969-0095.ch023.

22. Nowak, J.; Florek, M.; Kwiatek, W.; Lekki, J.; Chevallier, P.; Zięba, E.; Mestres, N.; Dutkiewicz, E.M.; Kuczumow, A. Composite structure of wood cells in petrified wood. Materials Science and Engineering: C 2005, 25, 119-130, http://dx.doi.org/10.1016/j.msec.2005.01.018.

23. Oriol, E.; Raimbault, M.; Roussos, S.; Viniegra-Gonzales, G. Water and water activity in the solid state fermentation of cassava starch by Aspergillus niger. Applied Microbiology and Biotechnology 1988, 27, 498503, http://dx.doi.org/10.1007/bf00451620.

24. Pandit, N.P.; Maheshwari, S.K. Optimization of cellulase enzyme production from sugarcane pressmud using oyster mushroom - Pleurotus Sajor-Caju by solid state fermentation. J Bioremediation and Biodegradation2012, 03,http://dx.doi.org/10.4172/2155-6199.1000140.

25. Pérez, J.; Muñoz-Dorado, J.; de la Rubia, T.; Martínez, J. Biodegradation and biological treatments of cellulose, hemicellulose and lignin: an overview. International Microbiology 2002, 5, 53-63, http://dx.doi.org/10.1007/s10123-002-0062-3.

26. Sirohi, R.; Singh, A.; Malik, S. Production, characterization and industrial applications of cellulase derived from agro-waste. Current Journal of Applied Science and Technology2018, 27, 19,https://doi.org/10.9734/CJAST/2018/41302.

27. de Almeida Antunes Ferraz, J.L.; Souza, L.O.; Soares, G.A.; Coutinho, J.P.; de Oliveira, J.R.; AguiarOliveira, E.; Franco, M. Enzymatic saccharification of lignocellulosic residues using cellulolytic enzyme extract produced by Penicillium roqueforti ATCC 10110 cultivated on residue of yellow mombin fruit. Bioresource Technology 2018, 248, 214-220,http://dx.doi.org/10.1016/j.biortech.2017.06.048. 
28. Ahmed, A.; Khan, M.; Ahmad, A.; Khan, S.; Sohail, M. Optimization of pectinase production from Geotrichum candidum AA15 using response surface methodology. Pakistan Journal of Botany 2018, 51.

29. Ding, X.; Yao L.; Hou, Y.; Hou, Y.; Wang G.;Fan, J.;Qian, L. Optimization of culture conditions during the solid-state fermentation of tea residue using mixed strains. Waste Biomass Valorization 2020, https://doi.org/10.1007/s12649-019-00930-4

30. Sazci, A.; Erenler, K.; Radford, A. Detection of cellulolytic fungi by using Congo red as an indicator: a comparative study with the dinitrosalicyclic acid reagent method. Journal of Applied Bacteriology 1986, 61, 559-562,http://dx.doi.org/10.1111/j.1365-2672.1986.tb01729.x.

31. Islam, F.; Roy, N. Screening, purification and characterization of cellulase from cellulase producing bacteria in molasses. BMC Research Notes 2018, 11, http://dx.doi.org/10.1186/s13104-018-3558-4.

32. Singhania, R.R.; Sukumaran, R.K.; Pandey, A. Improved Cellulase Production by Trichoderma reesei RUT C30 under SSF Through Process Optimization. Applied Biochemistry and Biotechnology 2007, 142, 60-70, http://dx.doi.org/10.1007/s12010-007-0019-2.

33. Li, C.X.; Zhao, S.; Luo, X.M.; Feng, J.X. Weighted Gene Co-expression Network Analysis Identifies Critical Genes for the Production of Cellulase and Xylanase in Penicillium oxalicum. 2020, 11, http://doi.org/10.3389/fmicb.2020.00520.

34. Medouni, L.; Zaidi, F.; Adrar, S.; Kecha, M. Olive pomace: from an olive mill waste to a resource , an overview of the new treatments. 2018, 05, 1-6, https://dx.doi.org/10.22159/jcr.2018v5i5.28840.

35. Shruthi, B.R.; Achur, R.N.H.; Nayaka Boramuthi, T. Optimized solid-state fermentation medium enhances the multienzymes Production from Penicillium citrinum and Aspergillus clavatus. Current Microbiology 2020,https:// doi.org/10.1007/s00284-020-02036-w.

36. Osma, J.F.; Moilanen, U.; Toca-Herrera, J.L.; Rodríguez-Couto, S. Morphology and laccase production of white-rot fungi grown on wheat bran flakes under semi-solid-state fermentation conditions. FEMS Microbiology Letters 2011, 318, 27-34, http://dx.doi.org/10.1111/j.1574-6968.2011.02234.x.

37. Watanabe, H.; Noda, H.; Tokuda, G.; Lo, N. A cellulase gene of termite origin. Nature 1998, 394, 330-331, http://dx.doi.org/10.1038/28527.

38. Zaldivar, J.; Nielsen, J.; Olsson, L. Fuel ethanol production from lignocellulose: a challenge for metabolic engineering and process integration. Applied Microbiology and Biotechnology 2001, 56, 17-34, http://dx.doi.org/10.1007/s002530100624.

39. Kaur, P.; Taggar, M.S.; Kalia, A. Characterization of magnetic nanoparticle-immobilized cellulases for enzymatic saccharification of rice straw. Biomass Conversion and Biorefinery 2020, https://doi.org/10.1007/s13399-020-00628-x

40. Sabae, S.Z.; Eldourghamy, A.S.; Aly, S.A.; Rizk, N.M.H. Ahmed Sobhy. Immobilization of lignin peroxidase from Alcaligenes aquatilis and its application in dye decolorization. Letters in Applied NanoBioScience 2020, 9,1058-1063,https://doi.org/10.33263/LIANBS92.10581063. 